\title{
Erratum to: Porcine epidemic diarrhea virus: An emerging and re-emerging epizootic swine virus
}

\author{
Changhee Lee
}

\section{Erratum}

After the publication of this work [1], we noticed that an incorrect version of Fig. 5 (Fig. 1 here) was published. The correct version of Figure five has now been updated in the original article and can also be seen below. The publisher apologises for any inconvenience caused.

Received: 5 January 2016 Accepted: 8 January 2016

Published online: 01 February 2016

\section{Reference}

1. Lee C. Porcine epidemic diarrhea virus: An emerging and re-emerging epizootic swine virus. Virology Journal. 2015;12:193. 


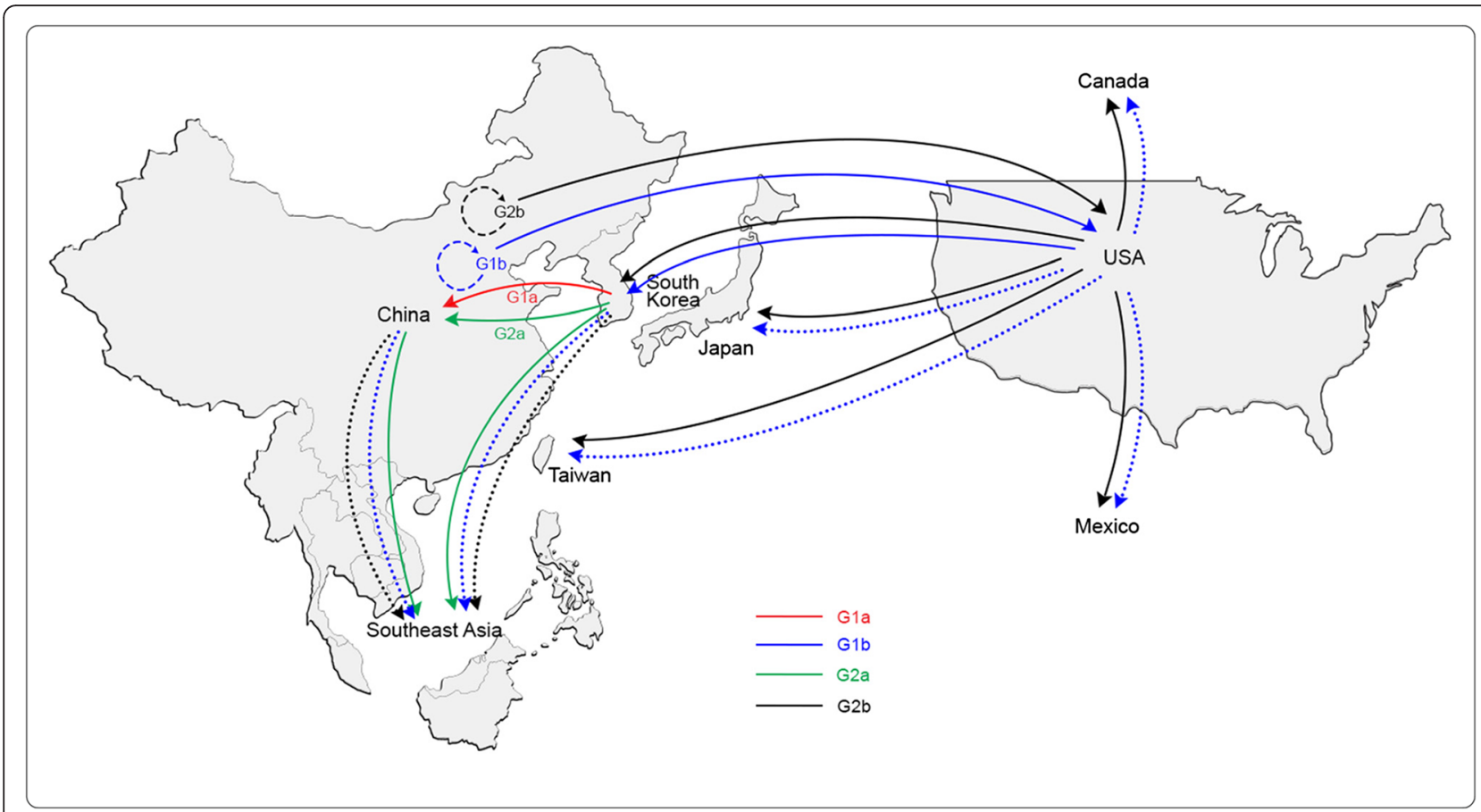

Fig. 5 From: Porcine epidemic diarrhea virus: An emerging and re-emerging epizootic swine virus 